原 著〔実践研究〕

\title{
小学生の動物概念学習における縮小過剰型誤概念の 修正に及ぼす境界的事例群の効果
}

\author{
荒 井 龍 弥 $^{1}$ 宇 野 忍 ${ }^{2}$ 工 藤 与志文 ${ }^{3}$ 白 井 秀 明 4
}

本研究では, 縮小過剩型の誤概念として小学生の動物概念を取り上げ, この誤概念を科学的な概念に 修正するための境界的事例群を用いた教授法の効果を検討した。本研究の中心的仮説は, 境界的事例群 を用いた教授により縮小過㮃型誤概念が修正されるであろうというものであり，この仮説を検証するた めに，3つの実験が行われた。実験はいずれも，小学校 5 年生を対象とした理科の授業として行われ， 事前テスト, 自作のビデオ教材の視聴と視聴後の話し合いによる教授, 事後テストという３つのセッショ ンで構成された。境界的事例群として水中のプランクトン事例群及び貝事例群を単独で用い, 食べる, 動く, 排泄するシーンを示すビデオ教材の視聴を行った第 1 , 第 3 実験では，概念の組みかえを示す結 果は得られなかった。境界的事例としてプランクトン事例と貝事例群を用いたビデオ教材の視聴を行っ た第 2 実験では，すべての課題の正答率が大幅に増加し，仮説を支持する結果を得た。これらの結果か ら, 縮小過剩型詋概念の修正には，2 種の境界的事例群の対提示が有効であることが確認された。

キーワード：概念学習, 誤概念, 動物概念, 教授法, 小学生

\section{問 題}

教科教育においてある概念の学習が目標とされる場 合，学習者が当該概念と対応する誤概念ないし誤ルー ルを学習以前に持っていること，さらに，そうした誤 概念・誤ルールが, 子どもたちの学習活動に妨害的な 影響を与えるということが多くの研究で見出されてい る。細谷(1996)はこの種の誤ルールについて,「過去の 狭い偏った範囲の経験の自成的一般化の結果として作 られ, ルール命題における前提項や帰結項の選びまち がえ, 選びすぎ，選び不足や，適用範囲の拡大過剩や 縮小過剩などの特徵を持つ」としている。細谷のいう 適用範囲の縮小過㮃という特徵を持つ概念としてょく 知られているものに「動物」概念がある。

言うまでもなく，生物学的概念としての「動物」は， 他の生物によってつくられた有機物を拱取して生きて いるという点で，無機物から有機物を合成できる「植 物」と対立的にとらえられる生物のことである。この 「従属栄養」という特徵を中核とし, それに連関する諸 特徵に基づいて生物界の一部を包括的にとらえるとい

仙台大学

東北大学

東北大学 (現所属 札幌学院大学

東北福祉大学
うのが生物学的な動物概念の本質であろう。しかしな がら，近年，子どもたちの持つ概念に関する関心が高 まるにつれ，上述のような生物学的概念とは異なった 内容の動物概念の存在が広く知られるようになってき た。例えば, Bell (1981) によるニュージーランドの子 どもを対象にした調查によれば, 動物の特徵として, 足の数 (4 本), 体の大きさ (昆虫より大きい), 生息地 (陸 上), 体毛の有無(毛がある), 発声の有無(声を出す)といつ たものをあげており，概して陸生の四足哺乳類に限定 してカテゴリー化しているという。また, Mintzes 他 (1991) も米国の子どもを対象にした同様の調査におい て,「動物」という名称が哺乳類と鳥類に限定的に使用 される傾向があることを報告している。さらに, 荒井 (1990) は, 日本の小学 5 年生を対象に動物概念の外延と 内包の判断を行わせる調査を行い，(1)外延に関しては いわゆる大型の四足哺乳類に限定されている(2)内包に 関しては「卵生／胎生」「声を出す／出さない」「毛が ある/ない」といった不適切属性を外延の判断基準と することが多いものの, 特定の不適切属性に一貫して 着目しているわけではない(3)「運動」「捸食」「排泄」 といった科学的に妥当と考えられる属性のみを手がか りとした者が少ない, などの結果を得ている。

以上の一連の結果は, 外延的側面については適用範 囲が限定的（縮小過剩）である点で，内包的側面につい 
ては不適切な属性が追加されているという点で, 生物 学的に妥当とされる概念と異なる動物概念が広く形成 されていることを示唆しているものと思われる。もち ろん,「動物」という名称をケモノ類に限定して使用す ることは，言語使用の文脈によっては必ずしも誤りと はならず，文脈による意味の使い分けの問題に還元し うるとする解秎も成り立つだろう。しかし, 荒井(1989, 1995)は，このような解釈が楽観的にすぎることを具体 的に示している。荒井は小学 5 年生を対象に, 子ども たちの分類上の誤りを指摘し,「動物」の生物学的に妥 当な定義を直接教示する方法を用いて, 上述の誤概念 の修正を試みた。具体的には，「動物はみんな，動い て, エサ食べて, ウンチする」というルールを提示し た後, カエル・ヘビ, スズメ・ワシ, サメ・キンギョ, チョウ・トンボなどが動物かどうかを問いながら, 生 き物 $\rightarrow$ 動物 $\rightarrow$ 哺乳類 - 爬虫類・両生類…のようなカテ ゴリーの階層構造を教示するという授業を行った。そ の結果, ルールを教示した後でも相変わらず不適切属 性を判断基準として用いることに固執する子どもが存 在することがわかった。また，授業後の評価課題の結 果から，この方法が誤概念の修正には必ずしも有効で はないことが明らかにされた。䛊った動物概念の外延 を挔大する教示に学習者が抵抗するという同様の報告 は, Osborne \& Freyberg (1985) においてもなされて いる。このように，「動物」に関する縮小過剩型誤概念 は, 通常の教示では修正が困難であるという「誤概念」 の一般的特徵を有していることになり, 言語使用の問 題というよりもむしろ生物学的な動物概念形成という 観点から熟考されるべき問題であると考えられる。当 然のことながら, 生物学的に妥当な動物の定義や分類 体系は学習者が形成した誤概念とは独立に構成された ものであり，それらを一方的に教えこんでも誤概念は 容易に修正されないのであろう。むしろ, 誤概念の存 在を考慮に入れ, 誤概念を生物学的に正しい概念に組 みかえる教授方略の工夫が必要とされるのである。

本研究では, そのような教授方略を構成する要素と して, 概念を教授する際の「提示事例」の選択に着目 する。すでに, 細谷 (1976) は誤ルールシステムの組み かえに関して, 誤ルールに基づいて予想すると学習者 が誤りをおかすような事例を学習の初期段階で使用す るストラテジー(ドヒャ一型ストラテジー) を提唱してい る。このような学習者の知識と矛盾する事例の有効性 は経験的に広く知られており,「概念変化」に興味を持 つ研究者のみならず，「仮説実験授業」をはじめとする 現場の教育実践においても様々な形で用いられている
(Chinn \& Brewer, 1993; 山崎, 1994)。さらに，伏見 (1995) は縮小過剩型誤概念の適用範囲を拡大するには, 学習 者が事前に正しく当該概念に属すると判断している事 例 (正事例) よりも, 誤って当該概念に属さないと判断 している事例 (誤知事例) を焦点事例とするのが有効で あることを明らかにしている。

以上の点, 特に伏見の見解をふまえれば，本研究の 場合でも学習者が詿って動物だとは考えていないよう な動物を事例として使用することが動物概念の外延の 拡大に効果的であることが予想されるのである。しか し，そのような「䛊知事例」に相当すると考えられる 例は極めて多様であり，それらが一様に有効であると は考えにくい。そこで，どのような性質を備えた「詋 知事例」を選択するのが最も効果的であるのかといつ た問題を追求する必要がでてくる。しかし，この点に 関しては, 細谷も伏見も言及していない。

すでに, 人工概念学習研究において, 不適切属性の 值が事例間でなるべく異なるように正事例を組み合わ せることが，効率のよい概念達成のための条件の一つ として指摘されている(例えば Tennyson, Woolley \& Merrill, 1972 ; Houtz, Moore \& Davis, 1973)。不適切属性值が 正事例間で大きく異なることで, 適切属性と不適切属 性の弁別がしやすくなり，不適切属性を誤って適切属 性と判断する可能性が少なくなると考えられるからで ある。このことは誤知事例の選択について一定の示唆 を含んでいるといえよう。ただし，人工概念の学習で は，学習対象たる概念に対応する概念を学習者が既に 形成しているということは考えられないのであり，そ の点で本研究で取り上げるような概念学習と本質的に 異なっている点も考慮に入れなければならない。した がって, 人工概念の学習では単にすべての不適切属性 が正事例間で互いに異なった值を取るように事例群を 選択すればよいのに対し，誤概念が形成されている場 合の概念学習では, 学習者が誤って適切とみなしてい る不適切属性の値が正知事例となるべく異なるように 誤知事例を選択する必要があることになろう。例えば, 学習者が容易に動物と判断する正知事例 (例えば,クマ) は四本足で, 昆虫より体が大きく, 陸に住み‥といっ た具合で, 学習者が誤って適切だとみなす傾向がある 不適切属性值を数多く有している。この場合, 誤知事 例としては多様な動物を選択することができるが，仮 にカエルを選択した場合, 四本足で体も昆虫よりは大 きく陸に住んでいる…というように, 上述の不適切属 性值の多くは正知事例と共有したものになろう。一方, 四本足ではなく, 体が小さく, 水中にすみ. といった 
ように異なる不適切属性值をなるべくたくさん有する 動物（例えば，ミジンコ）を誤知事例として選択すること も可能である (TABLE 1 参照)。そして，これまで展開し てきた議論からすれば，後者のような事例を提示した 方が，適切属性と不適切属性の弁別が容易になり，誤 概念の修正が進むのではないかと考えられるのである。 そこで本研究では，この種の事例，すなわち誤知事例 の中でも「学習者が誤って適切属性と取り違えている 不適切属性において, 学習者が適切と考えている值と は異なった值を多く有する事例」を「境界的事例」5 と呼 ぶことにし，提示事例として積極的に選択することに する。本研究の中心的な仮説は，「境界的事例群」を採 用した教授活動により，適用範囲の縮小過剩型誤概念 が修正されるであろうというものであり，この仮説の 検証が本研究の目的となる。

\section{実 験 I}

\section{目的}

本実験の目的は動物概念の修正に及ほす境界的事例 群の有効性を検討することである。実験はその結果の 生態学的妥当性を高めるため, 理科の授業の一環とし て実施することが計画された。本実験ではこれまでの 研究成果から, 不適切属性のうち, 大きさ・声を出す か・生息地・移動形態といった属性群について異なっ

TABLE 1 事例の属性構造

\begin{tabular}{|c|c|c|c|c|c|c|c|c|c|c|}
\hline & & クマ & ヒr & ススメ & 力エル & トンボ & $\cdots$ & ア+サリ & ミジン & ソウリムシ \\
\hline \multirow[t]{2}{*}{ 適 } & 動き回るか & + & t & + & t & + & & + & + & + \\
\hline & エサを食べるか & t & + & + & + & t & & + & + & + \\
\hline 切 & フンをするか & + & + & + & + & + & & + & + & + \\
\hline \multirow{2}{*}{ 不 } & 4 足加 & + & - & - & + & - & & - & - & - \\
\hline & 体は大きいか & + & t & + & + & - & & - & - & - \\
\hline 適 & 陸捿汃 & + & + & + & + & t & & - & - & - \\
\hline \multirow{2}{*}{ 切 } & 声を出寸加 & + & + & t & + & - & & - & - & - \\
\hline & 毛はあるか & + & t & t & - & - & & - & - & - \\
\hline
\end{tabular}

ここで言う「境界的」は，動物と植物の中間的存在というよ うな生物学的な意味を持つものではない。操作的には TABLE 1 に示されるように適切・不適切属性値の組み合わせによって定 義可能であるが, 学習者の知識構造に対応させて述べると次の ようになる。すなわち, 当該概念に属する全事例について, 学 習者がその概念の外延として判断しやすいものから順に，カテ ゴリーの中心から周辺へ配列したとするならば, TABLE 1 の不 適切属性值が一になる属性数が多い事例ほど, 学習者はその事 例を当該概念の外延と判断しにくいと想定され，結果的にカテ ゴリーの周辺ないし境界近くに位置づくことになる。このよう な事例を本論文では「境界的」と名付けたのである。縮小過㮃 型誤概念を有する学習者にとっては, その概念の外延であるこ とが自明である事例ほど中心部に位置し，境界付近に位置づく 事例は，もはや外延であるとは考えられないだろう。
た値を最も多く有すると考えられるミジンコ・ゾウリ ムシなどの小型及び中型のプランクトンを境界的事例 として選択した。

ところで, 通常の授業においては学習者の発言や雾 囲気等に対応する形で教授者の発問順序や使用する資 料が多様に変化しうる。そこで自作プリント及びビデ 才教材を用いることにより，結果的にこれらの検討外 要因の変動が抑制され，境界的事例を用いた教授活動 そのものの効果がより明確にしうると考えられる。そ こで，教授活動はビデオ教材の視聴を中心とした自作 プリントに基づいて行われた。

なお教授目標は,「運動」「攝食」「排泄」を動物の 3 大特徴として理解させ，それに基づいて動物の行動及 び形態的側面に関して適切な推論 (動物概念の適切属性の 特定)をできるようにさせることである。具体的には以 下のような推論を可能にさせることが目標となろう。

i ）「食べる」「フンをする」「口がある」などといった 「動物」概念の適切属性值群を正しく指摘することが 可能となる。(内包的側面)

ii）ある生物が「食べる」のならその動物は「肛門が ある」だろうといった動物概念の適切属性值群間の 関係を正しく予想することが可能となる。(属性相互 関係)

iii）「動物」概念の外延的側面が広がり，多くの動物を 正しく同定することが可能となる。(外延的側面)

iv）内包と外延両者の関係を正しく予想することが可 能となる。(内包一外延相互関係)

誤概念の修正は以上の教授目標の実現という形で具 体化されるであろう。

なお，本研究で目指す動物概念の修正に対する教育 的意義についても一言しておく。小学 $3 \sim 6$ 年の理科 教育において, 成長の過程や体のつくり・活動と環境 との関わり・発生や成長など, 動物を含めた生物単元 は各学年に設けられている。しかも，各単元では動物 全体にわたって当てはまることがらの理解が求められ ている場合が少なくなく，いわゆる典型的な動物にの み学習結果が限定されることは望ましくない。それゆ え，学習者の持つ「動物」概念をより広い概念に修正 しておくことによって, 学習内容の適用対象がより広 がることになると考えられるのである。

\section{方法}

学習者 仙台市内 $\mathrm{S}$ 小学校 5 年生 37 名（女子のみ）

期 日 1994年 4 月〜 5 月

手続き 理科単元「魚のそだちかた」の一部として 当該教授活動が行われた。教授活動の前及び直後に同 
一課題からなる事前・事後テストを課した。所要時間 は事前テスト 40 分, 教授活動と直後に行われた事後テ ストをあわせ 80 分であった。

教授活動 教授活動は, 動物プランクトン(ミジンコ・ ゾウリムシ・アメーバ）について，植物プランクトンと対 比させつつ, 運動・拱食・排泄が動物固有のくらしぶ りであることなどを説明した「水の中の生き物」とい う題の自作ビデオ教材の視聴を中心とし，さらに視聴 前後の「視聴内容の確認」を加えた 3 部分からなる。 視聴内容の確認は, 自作プリントを用いた通常の一斉 授業の形で行われた。視聴前の確認では, メダカはど んなところに住んでいるか, メダカの住んでいる池な どには他にどんな生き物がいるかなどを問い, ビデオ 視聴の導入とした。視聴後の確認では, ビデオに登場 した動物の図を用意し, 各器官の部位とその働きにつ いて再確認した。(視聴内容の確認」における発問の内容は, 以後の実験においてもほほ同一である。)

評価課題 評価課題は全部で 4 問からなり, 先の予 想の i ) iv) に対応している。以下, 分析の対象とす る小問数を含め, 各課題の内容を説明する。

\section{i )内包課題 (内包的側面の理解)}

動物であることが既知である場合に，種々の属性の 值を予想させる課題である。適切属性に関連する小問 5 項目（動き回るか，何かを食べるか，ウンチをするか，口があ るか, こうもんがあるか) 及び不適切属性に関する小問 6 項目（声を出すか,どこにすんでいるか, 毛があるか,こん虫より 大きいか, 歯があるか, 足が 4 本あるか) からなる。

\section{ii）属性関係課題（属性相互関係の理解）}

ある生物について「食べる」ことが既知である場合 に, 他の適切属性群の值を予想させる課題である。小 問は「食べる」に関する項目をのぞいた点以外は内包 課題と同じであり, 適切属性を尋ねた小問 4 項目と不 適切属性を尋ねた小問 6 項目からなる。

iii）外延課題 (外延的側面の理解)

個々の生物名を与え, それが動物に属するか否かを 判断させる課題である。尋ねた生物種は, 脊椎動物(哺 乳類, 鳥類, 両生類, 魚類) 及び無脊椎動物 (貝類・昆虫類) 各 1 種及びヒト, さらに教授活動中に説明されるプラン クトン類 3 種及び植物 1 種の計11種である。結果の検 討は, 学習者が熟知していると考えられる動物 7 種(ク マ,スズメ,カエル, ヒト,メダカ,トンボ,アサリ) を主たる対 象とする。

iv) 内包一外延関係課題 (内包一外延相互関係の理解)

生物名を提示し, 5 つの適切属性 (内包課題と共通) の 值を予想させる課題である。生物は外延課題の生物に
加え, さらにカタッムリなど 3 種を加えた計15種であ る。生物ごとに一貫して 5 属性に「見たことがある」 「ありそう」と判断したものを正答とした。結果の検討 は，学習者が熟知していると考えられる動物 10 種(上記 7 種にアメンボ, ホタル, カタッムリを追加）を主たる対象と する。

\section{結果}

学習者37名のうち, 事前・事後の評価課題のいずれ にも回答したのは35名であった。以下では, この35名 について検討する。教授活動中の様子では, 教授内容 について特に抵抗は示さず, 個々の事例及びその説明 について違和感を表明するなどのことはなかった。

評価課題の平均正答数, 及び完答者の人数を TABLE 2 に示す 6 。事前の結果を見ると, 外延課題の 7 動物

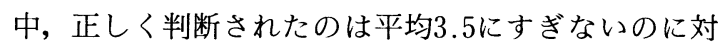
し, 内包課題の適切属性 5 項目の平均正答数は 4.7 と高 いことがわかる。このことは前述の先行研究と同じく, 本実験における学習者も, 適切属性は正しく判断でき るものの, 不適切属性を誤って適切属性と判断し, そ の結果, 外延の「縮小過剰」が起きていることを意味 する。また, 事前と事後の変化を検討すると, 外延課 題をのぞいたいずれの課題についても平均正答数及び

TABLE 2 各問の平均正答数と完答者数の比較

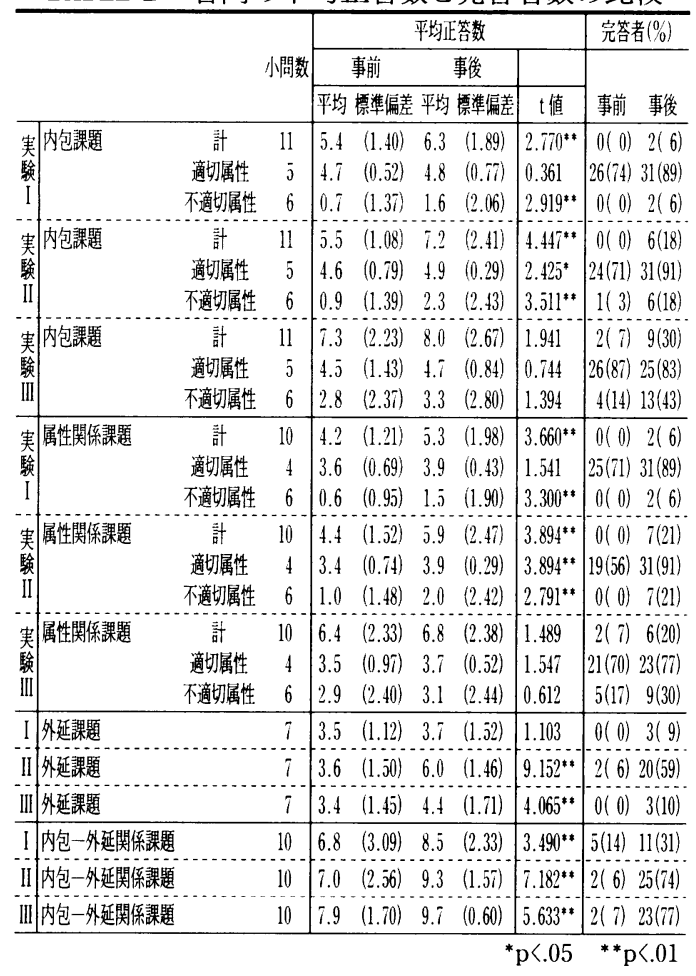


完答者数に若干の増加が見られたものの, 全体として は決して満足すべき結果とはいえないことがわかる。 このことは, 学習者の持つ動物概念がかなり安定した 状態であり, 変化修正が起こりにくいという荒井(1990) の結果と残念ながら一致する結果であることを意味し よう。

以下課題ごとに，より詳細に検討することにする。 内包課題の適切属性 5 項目については, 事前から高い 正答率が示されたのに対し, 不適切属性では正答が「わ からない」(不適切属性であるので,いかなる値をとるか予測で きない)であったためか, 正答率は低かった。この 6 項 目に一貫して誤答した（特定の値を予想した）者は，25名

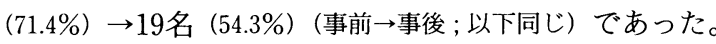
この傾向は属性関係課題でもほほ変わらず, 不適切属 性に対する一貫誤答者は，22名 $(62.9 \%) \rightarrow 17$ 名 (48.6\%) と依然として半数近くを占めた。限定された情報から 結論（ここでは不適切属性値の決定）を保留することができ るためには, 適切属性と不適切属性の間の厳密な区別が 求められる。この一貫誤答率の高さは, この区別が事後 においても不完全であることによると考えられる。

さらに，外延課題及び内包一外延関係課題の事後正 答率をそれぞれ FIGURE 1, FIGURE 2 に示す(なお,内包 外延関係課題の結果は，外延課題と共通する動物のみ示す。さ らに，教材に登場するゾウリムシ・アメーバの結果も加えてあ る)。外延課題では, 平均正答数の変化はほとんど見ら れず，トンボやアサリの正答率がきわだって低いこと がわかる。

また, 内包一外延関係課題では，平均正答数が事後 で増加しているものの，アサリの事後正答率が極端に 低い $(31 \%)$ ことから, 結果が生物ごとに一様ではない ことがわかる。このことは，アサリを除いた 9 種につ いて完答者数を算出すると, 13 名 $(37.1 \%) \rightarrow 28$ 名 $(80.0 \%)$ と，かなりの増加が認められることからもうかがえる。 考察

今回の結果では，小幅な正答率の上昇があったとは

6 授業を対象にした研究に扔いて統計的検定を使用する場合, 次のような問題が生じるものと想定される。(1)授業においては 学習者間の相互作用が発生しているので, 同一クラスの個々の 学習者を互いに独立な標本と見做すことはできない。(2)母集団 として「同様の傾向を持つ小学 5 年生」を想定した場合, そも そもこのクラスの子どもが標本として代表性を備えている保 証はない。(3)実践研究という性格上, 特定の操作の有効性は教 授目標の可否と照合して判断されるべきものであり, 検定に よって帰無仮説が棄却されたからといって, 有効性が確認され るわけではない。以上のような問題点が存在することをふま え, TABLE 2 に掲載した検定結果はあくまで参考程度にとどめ るものとする。

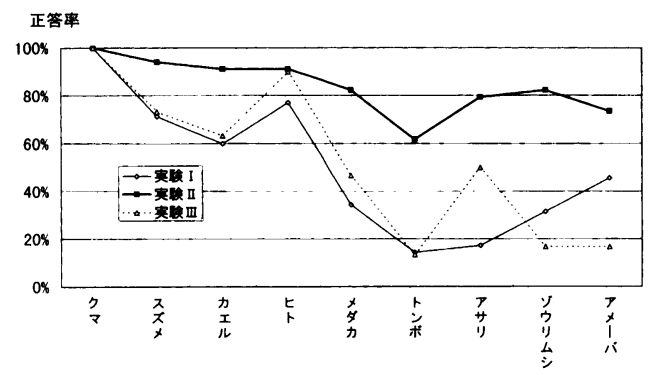

FIGURE 1 外延課題の正答率の比較 (事後)

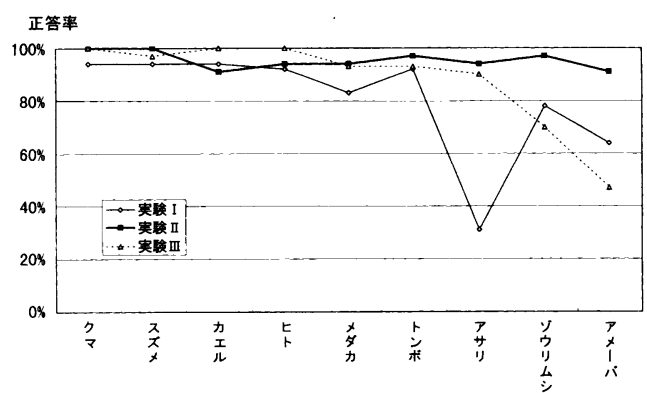

FIGURE 2 内包一外延関係課題の正答率の比較 (事後)

いえ，学習者全体の概念の大幅な組み直しを印象づけ るような大きな変化が見られなかった。このことは教 授活動が, 学習者既有の動物概念とは直接関わらず, いわば付加的な情報としてのみ働いた，ということを 示すと思われる。すなわち，事前にはほとんど未知で あった事例が示されたことによって，動物概念の内包 及び外延とも，その適切属性及び不適切属性の判断基 準に若干の追加もしくは修正が行われたにすぎないと いってよいと思われる。この結果は, 既知の生物名及 び適切属性が明記されており，この意味で手がかりの 多い内包一外延関係課題の正答率の増加となって現れ た。ただし，「アサリ」に関してはその限りではない。 以上の結果から，今回の教授活動は主として外延・ 内包相互関係について若干の影響を及ぼしたものの, (1)全体として質的変化をもたらすに至らなかった (2) 「アサリ」に対して特異的に効果が見られなかった，と いった問題点が明らかとなった。これらの問題点を解 決するために，教授活動にいかなる改訂を加えるべき かという点については, 様々な観点から改訂の方向を 探ることができる。ただし，境界的事例群の効果を検 討するという本研究の主旨からすれば，「アサリ」も境 界的事例に相当する特徵を備えているという点は重要 である。すなわち，今回の結果は，必ずしも境界的事 例群そのものの無効性を意味するものではなく, 境界 的事例群の選択において，アサリ等の貝類を加えるな 
ど，さらなるバリエーションが必要であることを示唆 するものと思われる。したがって，貝類を新たに境界 的事例群に加えることによって教授目標の実現が可能 になるかどうかを検討する必要が出てくるだろう。

\section{実 験 II}

\section{目的}

実験 I から，アサリなどの貝類が境界的事例として 重要な位置を占めている可能性が示唆された。した がって, 教授活動の改善という観点からすれば, アク ションリサーチ的手法によって, 実験 I で取り上げた 「プランクトン事例群」の他にアサリなどの「貝事例群」 も取り上げて, 提示する境界的事例群のバリエーショ ンを増やすことが考えられる。そこで, 実験 II では, 実験 I の「プランクトン事例群」を提示したビデオの 他に,「貝事例群」の生態を示す手段として「水の中の

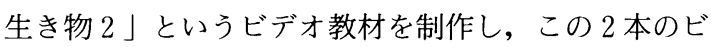
デオを用いた教授活動を行い, その有効性を検討する ことを目的とする。

\section{方法}

学習者 仙台市内 $\mathrm{S}$ 小学校 5 年生 34 名 (女子のみ)

期 日 1995年 4 月

手続き 単元「魚のそだちかた」の始めの部分に当該 教授活動が行われたこと,教授活動の前及び直後に同一 課題からなる事前・事後テストを実施したことは実験 I と同様である。所要時間は事前テスト 40 分, 教授活動 80 分, 事後テスト40分で, 3 日間に分けて行われた。

教授活動 教授活動の後半部に,「水の中の生き物 $2 」$ のビデオ視聴と視聴後の「視聴内容の確認」が付 け加わる点のみが, 実験 I と異なる。「水の中の生き物

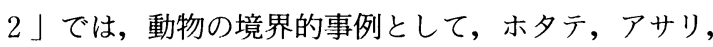
ヨメガカサガイ, アオヤギなどの貝事例群が登場し, それらの運動や摂食の様子が映像で示されるとともに， 運動・攝食・排泄のための器官が貝類にも備わってい ることが解説される。また, 視聴後の確認では, アサ リを例にあげ，運動・摄食・排泄のための器官を特定 する作業を行い,さらに「貝が足を使うのはどんな時 か」について確認した。これらの活動はあくまで,「水

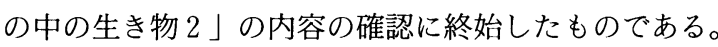
しかし，このような確認活動により，「プランクトン事 例群」について学習した内容が「貝事例群」にも適用 できることを理解しやすくなると考えた。

評価課題 実験 I と同じである。 結果

各評価課題の平均正答数, 及び完答者数を TABLE 2
に示す。また，外延課題及び内包一外延関係課題の事 後正答率をそれぞれ FIGURE 1, FIGURE 2 に示す。事前 テストの結果は，実験 I のものとほとんど変わりがな かった。したがって, 学習者の事前の知識状態はほぼ同 様であると考えられるので,ここでは実験 I の結果とも 比較しながら，実験 II の教授活動の効果を検討する。

内包課題では, 適切属性に対して一貫して正答した 者が24(71\%) $\rightarrow 31(91 \%)$ と増加した。また，不適切な 6 属性に一貫して誤答 (特定の值を予想) した者は18 (53\%) $\rightarrow 15$ (44\%) と減少し，逆にこれらの 6 項目に一貫して 正答 (判断を保留) した者は $1(3 \%) \rightarrow 6(18 \%)$ と増加し ていた。

この傾向は属性関係課題でも変わらず, 適切属性の 5 項目に対する一貫正答者は $19(56 \%) \rightarrow 31(91 \%)$ と大 幅に増加して抢り，不適切な 6 属性については一貫誤

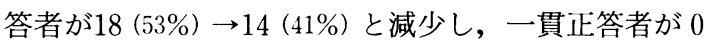
$(0 \%) \rightarrow 7(21 \%)$ と増加していた。このように, 不適切 属性に関して一貫して判断を保留する反応が, 実験 I に比べて増加していることがわかる。

外延課題では, 事前から正答率が高かったヒト及び クマを除くと，境界的事例として提示したアサリ，ゾ ウリムシ，アメーバをふくめてすべての動物に関して， 事前から事後への大幅な伸びが認められた。学習者が 事前から熟知していると思われる 7 動物の平均正答数 をみても， $3.6 \rightarrow 6.0$ と大幅な上昇を示した。これらの 伸びは，実験 I では認められなかったものである。

さらに, 内包一外延関係課題において, 適切な 5 属 性に一貫して「する・ある」と答えた完答者数が大幅 に増加していた。事後の正答率も，すべての動物にお いて $85 \%$ 以上という高い值を示した。

考察

ほぼすべての課題について，事前から事後へ，実験 I の結果をしのぐ成績の伸びが認められた。特に，外 延課題で, 境界的事例群を含めてすべて動物の正答率 が大幅に増加したという結果が得られた。この結果は, 実験 I では見られなかったことであり, 境界的事例群 として「プランクトン事例群」に「貝事例群」を付け 加えて提示したことが, 外延の拡大にとって有効で あったことを示すと考えられる。さらに, 内包課題, 属性関係課題及び内包一外延関係課題の結果は, 今回 新たに「貝事例群」を追加してバリエーションを持た せた境界的事例群が, 外延の拡大のみならず, 適切属 性と不適切属性の弁別や内包的側面と外延的側面の相 互関係の理解にとっても効果的であったことを示して いる。 
以上のように，「プランクトン事例群」と「貝事例群」 の両方を境界的事例群として提示したことにより, 学 習者が既に持っている「動物」概念の内包の組みかえ と外延の拡充が大幅に促進されたことが明らかになっ た。よって, 本実験の教授活動が, 適用範囲の縮小過 剩型誤概念の修正にとって有効であることが十分確か められたと言える。

しかしながら, 本実験で追加された「貝事例群」の 提示効果については, 単独提示しても同様の効果がも たらされるのか,「プランクトン事例」とともに提示し たことによる効果なのか特定できていない。このこと は, 第 1 に, 境界的事例として「貝事例群」のみを提 示しておけば学習者の「動物」概念を効率的に修正で きるのかという実践的な問題に関わる。第 2 に，同じ 境界的事例でありながら「プランクトン事例群」と「貝 事例群」は提示効果に違いがあるのかという理論的な 問題とも密接に関わる。そこで，これら残された問題 を明らかにするために, 実験IIIとして「貝事例群」を 単独で提示し，その効果を検討する。

\section{実 験 III}

\section{目的}

境界的事例としての「貝事例群」単独提示が動物概 念の修正に及ほす効果について検討する。

\section{方法}

学習者 仙台市内 $S$ 小学校 5 年生 30 名 (女子のみ)

期 日 1996年 4 月

手続き 実験 I・II と同様に，事前テスト (40 分) $\rightarrow$ 当該教授活動 (40 分) $\rightarrow$ 事後テストの順で実施した。

教授活動 メダカがミジンコなどのプランクトン類 を餌としていることを確認した後，メダカと同じ水の 中の生き物である貝類の生態を扱ったビデオ「水の中 の生き物 $2 」$ のを視聴させ, 視聴後に視聴内容の確 認を行った。

評価課題 実験II と同じものを使用した。

\section{結果}

各評価課題の平均正答数及び完答者数を TABLE 2 に示す。また，外延課題及び内包一外延関係課題の事 後正答率をそれぞれ FIGURE 1，FIGURE 2 に示す。

まず，外延課題では統計的に有意な差が認められた ものの, 実験IIのような成績の大幅な改善は認められ なかった。特にアサリについては，事例の一つとして 教授活動の中で提示したにもかかわらず，事後で約 50\%の正答率にとどまり，実験II の約 $80 \%$ という結果 には遠く及ばなかったことは注目に值する。
一方, 内包一外延関係課題では, 平均正答数が7.9 9.7 , 完答者が $2(7 \%) \rightarrow 23(77 \%)$ と大幅な改善が見られ た。このように実験 I にはなかった大幅な改善が見ら れたという点では, 実験 II と同様の結果といえる。

なお, 内包課題や属性関係課題については, 特に不 適切属性の事前正答率が実験 I やII りり高いため, 直接比べることはできない。しかし，平均正答数の事 前から事後への伸びを見ると, 目立った改善は認めら れず，この点では実験 I と同様の結果といえる。

\section{考察}

本実験では，境界的事例群として「貝事例群」のみ を提示して，適用範囲の縮小過剩型である動物概念の 修正を試みた。一定の効果が見られたのは，内包的側 面と外延的側面の関係の理解に関するもののみにとど まり，その他，外延的側面あるいは内包的側面の理解 などに関しては,「プランクトン事例群」と「貝事例群」 の両方を提示した実験 II の結果には及ばず,むしろ「プ ランクトン事例群」のみを提示した実験 I と類似した 結果が得られたと考えられる。

したがって，これらの結果からわかることは，同じ 境界的事例でありながら,「プランクトン事例群」や「貝 事例群」を単独で提示しても,「動物」概念の修正には あまり効果がないことである。特に，外延課題に注目 してみると, 本実験や実験 I のように各事例群を単独 で提示した場合は外延が十分に拡大されないばかりか, 提示した事例そのものでさえ正答率が低いことがわか る。「問題」の項で述べたように, 学習者の既有知識と 教授内容が矛盾する場合，概念修正に対する抵抗が生 じやすいことがしばしば指摘されているが，単独提示 の場合, この「抵抗」が学習者の一部に生じ，その結 果，外延の拡大も十分に進まなかったものと推測され る。実験IIのように両事例群を対提示した場合にのみ, この「抵抗」が回避され，外延が十分に拡大されたと 考えることができよう。

さらに, 実験 I との比較によって,「プランクトン事 例群」と「貝事例群」の提示効果の違いを検討したが, 明確な違いはほとんど見られなかった。唯一, 内包的側 面と外延的側面の関係の理解(内包一外延関係課題)に関し て,「プランクトン事例群」の単独提示をした実験 I りも,「貝事例群」を単独提示した本実験の方がより理 解の促進が見られた，という点が異なると言えるが，本 研究の結果からこの違いを説明することはできない。

\section{討論}

本研究は 3 つの実験を通じて,「境界的事例」を採用 
した教授活動により適用範囲の縮小過剩型誤概念が修 正されるであろうという仮説の検証を試みたものであ る。討論ではまず仮説の検討を行い，それからその結 果の示唆するものについて論じることとする。

\section{1.「境界的事例群」の有効性について}

境界的事例群の効果は 3 つの実験結果を直接比較す ることで検証可能である。内包課題に関しては，実験 Iにおいて正答数のわずかな上昇が見られたにすぎず, 完答者もほとんど増加しなかったのに対し，実験IIで は相対的に高い得点が得られた。一方，実験IIIでは最 も高得点が得られたものの, 事前の得点が特に不適切 属性で高く，他の実験の結果と単純に比較できない。 ただし, 得点の上昇は 3 実験中最も少なく, 天井効果 という解釈も成り立たない。以上のことから,「プラン クトン事例群」と「貝事例群」をともに提示した条件 で最も内包的側面の理解が進んだものと判断されよう。 属性関係課題についても, 内包課題と類似した結果で あり，同様の判断が可能であると考えられる。

また, 外延課題に関しては, 実験 I でほとんど得点 の上昇がみられなかったものの, 実験IIにおいて著し い上昇がみられ, 実験IIIでは実験IIのレベルに到達し なかったことから, 外延的側面の理解も「プランクト ン事例群」と「貝事例群」をともに提示した条件で最 も進んだものとみることができる。

さらに, 内包一外延関係課題は相対的に得点が高く, 特に実験II・IIIでは完答者も 7 割を越えた。したがつ て, 内包的側面と外延的側面の関係の理解については, 「貝事例群」固有の効果が示されたと解釈することがで きる。

以上の結果から総合的に判断すれば,「プランクトン 事例群」及び「貝事例群」をそれぞれ単独に提示する よりも対提示する方が有効であったことになる。特に 縮小過㮃型誤概念の適用範囲の拡大という目標に関し ては，対提示に著しい効果がみられた。逆に言えば, 本実験で取り上げた「境界的事例群」に関していえば, 各事例群の単独提示では, 縮小過剩型誤概念の修正に とって十分でないということがわかる。したがって， 「境界的事例群」の提示一般に関して成立する形で記述 された当初の仮説は修正を要することになろう。

\section{2. 事例の「組み合わせ効果」について}

上述のように, 本実験では「事例群」の対提示条件 が最も効果的であったが, この結果は事例の数が多い 方が効果的であったという事を意味しているのではな い点に注意が必要である。すなわち, 事例効果の単純 な加法性が仮定される場合でも同様の結果が得られる
可能性はあるが，実験結果を詳細に分析するとそのよ うな解釈は否定される。例えば，外延課題の結果を動 物別にみると，実験 I では「ゾウリムシ」「アメーバ」 といった教授活動で直接取り上げられた事例でさえ低 正答率のままであるのに対し，実験IIではそれらの正 答率が著しく上昇しているのである。同様に，教授活 動で取り上げられた「アサリ」は実験IIにおいて高正 答率を示しているのに対し，実験IIIでは $50 \%$ 程度の正 答率に落ちている。さらに,「トンボ」「メダカ」「カエ ル」「スズメ」といった直接教示していない事例におい て高正答率が認められるのは実験 II のみである。これ らの結果は，事例の効果がその事例の類似した範囲の 一般化にとどまり, それらの効果が加算されていくと いう解釈と対立するものであり, むしろ事例群どうし の組み合わせ効果が現れたものと解釈すべきであろう。 具体的には,「プランクトン事例群」や「貝事例群」単 独では，直接教示した事例でさえも「動物」として受 け入れられにくいが, ともに提示された場合には，直 接教示された事例のみならず，それ以外の事例にまで 外延が拡大されることを示している。本研究ではこの 組み合わせ効果をもたらす諸要因を特定することは不 可能であるが，事例の組み合わせ効果自体これまで十 分に着目されてこなかった現象であり,さらに追求さ れるべきテーマであると思われる。

\section{3. いわゆる「ドヒャー型ストラテジー」との関連}

すでに述べたように，細谷 (1976)によるドヒャ一型 ストラテジーの提唱は, 誤ルール修正のための教授方 略に関するお㧈まかな枠組みを提示したものであって, 詳細な具体化は後の研究にゆだねられてきた。この点 からすれば，「境界的事例」はドヒャー型ストラテジー に基づく事例選択の原則の一つを具体的に示したもの であると言えよう。さらに, 事例の組み合わせ効果の 存在が明らかになったことから，「境界的事例」を効果 的に使用するための条件の一つも示し得たことになる。 また, 事例の組み合わせ効果はドヒャー型ストラテ ジーの欠点を回避する働きを持つ可能性もある。細谷 (1976)はすでに,ドヒャ一型ストラテジーがうまく機能 しない場合, 学習者にとって単なるショックで終わる 場合もあれば, 結果そのものを否定したりすることさ え起こると指摘している。教授活動で直接取り上げら れた事例の正答率が低いという実験 I やIIIの結果が細 谷の指摘したような学習者の「ショック」や「抵抗」 の結果だとすれば，それを回避し得た実験 II の結果は ドヒャー型ストラテジーを有効に機能させる上で示唆 に富むものと考えられる。 


\section{4. 概念修正のメカニズムについて}

細谷 (1976) の言うように，ドヒャ一型ストラテジー による概念組みかえは必ずしも次なる思考の方向性を 明確に指示するわけではない。それでは，それぞれの 事例群はいかなる効果をもたらしたのであろうか。本 研究のデータでは断言しえないが，以下では事例群の 役割を考察することによって動物概念修正のメカニズ ムを推測することにする。

全体的傾向として, 内包と外延の関係が理解された としても，必ずしもそれが外延の拡大に結びつかない ということは, FIGURE 1 と FIGURE 2 の比較により明 らかである。この点について, 実験ごとに詳細に検討 してみると, プランクトン事例群と貝事例群がともに 提示された実験 II では内包一外延関係の理解と外延の 拡大が同時に生じたのに対し，一方の事例群のみ提示 された実験 I 及びIIIではそのような結果は得られな かった。もっとも，実験 I とIIIの結果が全く同じとい うわけではない。実験 I と実験III との最大の違いは, 実験IIIの内包一外延関係課題における完答者の割合が 著しく高いという点である。このことの一つの解釈と して, 貝事例群の提示により,「くらしぶり(移動·提食・ 排泄の方法)」に対応する器官及びその目的（移動·提食・ 排泄）が動物一般に共通するものとしてカテゴリー化 されたのではないかと考えることができる。貝事例群 の器官やその動きはいわゆる「典型例」のものとはか なり異質ではあるが，同じ移動・摂食・排泄という役 目を持っているのである。一方，プランクトン事例群 では器官がもともと分化していないことから，カテゴ リー化が促進されなかったと言えよう。これらのこと から，移動・攝食・排泄の方法のバリエーションとい う動物概念の内包の拡充が概念修正にとって有効であ り，貝事例群はこのことを促進したと言えるのではな いだろうか。一方，先に検討した組み合わせ効果から， 内包の拡充のみでは外延の拡大には直結せず，貝事例 群で起きた内包の拡充のもとで，適切属性を持ち合わ せた生物が動物であるとするルールを外延に適用する ことをすすめる効果がプランクトン事例群にあると考 えられる。すなわち，動物概念の修正は，(1)内包の拡 充(2)ルールの外延への適用の 2 相によって生起すると 考えることができよう。このメカニズムを実証するこ とが今後の課題となる。

\section{引用文献}

荒井龍弥 1989 小学生の「動物」概念における「誤
れる特殊化」について 東北教育学会第 47 回大会 発表資料

荒井龍弥 1990 小学生の「動物」概念における判断 基準について 日本教育心理学会第 32 回総会発 表論文集, 427 .

荒井龍弥 1995 理科のストラテジー 宇野忍(編著) 授業に学び授業を創る教育心理学 中央法規 Pp.187-202.

Bell, B.F. 1981 When is an animal not an animal? Journal of Biological Education, 15, 213-218.

Chinn, C.A., \& Brewer, W.F. 1993 The role of anomalous data in knowledge acquisition : A theoretical framework and implications for science instruction. Review of Educational Research, 63, 1-49.

細谷 純 1976 課題解決のストラテジー 藤永保 （編） 思考心理学 大日本図書 Pp.136-156.

細谷 純 1996 教科学習の心理学 中央法規

Houtz, J.C., Moore, W., \& Davis, J.K. 1973 Effects of different types of positive and negative instances in learning "nondimensioned" concepts. Journal of Educational Psychology, 64, 206-211.

伏見陽児 1995 「概念」教授の心理学 川島書店 Mintzes, J.J., Trowbridge, J.E.,Arnaudin, M.W., \& Wandersee, J.H. 1991 Children's biology : studies on conceptual development in the life sciences. In S.M.Glynn, R.H.Yeany, \& B.K. Britton (Eds.). The psychology of learning science. Hillsdale, NJ : Lawrence Erlbaum Associates. Pp.179-200.

Osborne, R., \& Freyberg, P. 1985 Learning in science : The implications of children's science. Portsmouth, NH : Heinemann. Educational Books.

Tennyson, R.D., Woolley, F.R., \& Merrill, M.D. 1972 Examplar and nonexamplar variables which produce correct concept classification behavior and specified classification errors. Journal of Educational Psychology, 63, 144-152. 山崎雄介 1994 教育内容としての「概念」とはどの ようなものか グループ・ディダクティカ(編) 学びのための授業論 勁草書房 Pp.76-98.

(2000.2.7 受稿, ’01.1.27 受理) 


\section{Teaching by Using Boundary Instances : Modifying Undergeneralized Misconceptions in Elementary School Children's Conceptual Learning About Animals}

Tatsuya ARai (Sendal College), Shinobu Uno (TohokU UnIVersity), Yoshifumi Kudō (Tohohu Universtis) And

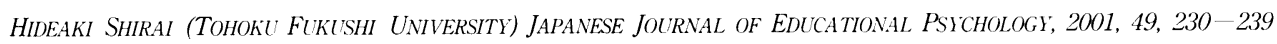

The present study focuses on elementary school children's undergeneralized misconceptions about animals, and examines the effectiveness for modifying these misconceptions of a teaching method using boundary instances. The main hypothesis was that elementary school children's undergeneralized concepts about animals could be effectively changed into a more scientific concept by teaching with boundary instances. 3 experiments were conducted to test this hypothesis; each experiment was performed in the context of classroom science teaching in elementary school fifth grade classes, and consisted of 3 sessions: pretesting, teaching and discussing with a videotaped aid, and post-testing. In the first and third experiments, plankton in water and shellfish respectively were adopted as boundary instances, and a videotaped aid that showed eating, moving, and excreting scenes for each respectively was used. The results of these 2 experiments did not clearly show conceptual change. In the second experiment, a revised version of the videotaped aid that treated scenes of both plankton and shellfish were used. The results showed that the ratio of correct answers increased greatly for all problems, and thus that the hypothesis was supported. The results demonstrated that teaching with paired use of 2 kinds of boundary instances is effective for modifying undergeneralized misconceptions.

Key Words : conceptual learning, misconceptions, concepts of animals, elementary school children 